in their establishment together with the length of their residence. This list is used in checking up the registrations. An effort was made to pass such a law at the last session of the Nebraska legislature, but this time the politicians were on guard and, after the bill had unanimously passed the house, it was buried in a committee of the senate.

\title{
POLICE TELEPHONES IN NEW YORK CITY
}

\author{
BY HENRY JAY CASE ${ }^{1}$ \\ New York
}

W

HEN a boy was lost in Peter Stuyvesant's time, the town crier clanged the warning through the lanes of Nieuw Amsterdam. To-day, the telephone speeds the alarm for lost boys, automobiles, murderers, thieves, over the length and breadth of Manhattan Island, and four other great boroughs as well, in less time than it took the town crier to get his staff and bell.

New York City is credited with being the most difficult city in the world to police. Its great area of land and water and its cosmopolitan population combined make it difficult to patrol. Some of the police precincts are larger than the biggest cities on the Atlantic coast. Some of them contain 250 miles of streets. The largest foot-post is two and one-half miles long. The largest bicycle post is 50 miles. Without electrical devices it would take an army corps to do so acceptably the work now performed by the small division of uniformed men.

Police telephone and flash-light lines completely wire the greater city, and the business transacted over this system is almost beyond belief. There are $6,000,000$ connections made annually from the telephone bureau alone. Police headquarters is directly connected with all police courts, hospitals furnishing ambulance service, district attorney and coroner's office, public and semi-public institutions and every elevated and subway station as well as ferry stations.

An alarm raised in any precinct of the city may be immediately flashed to headquarters, and from there to each one of the 96 precincts of the city, and even beyond into the region of the suburban zone in a remarkably short space of time-less time, indeed, than it takes to record the fact on paper. Railroad stations may be covered, bridges closed and ferries watched in case it is necessary to shut the doors of escape across the Hudson to New Jersey, or over the East river or the upper bay to Brooklyn or Staten Island. All this is done by men of the uniformed force sitting before the switch-board at headquarters, and through them by the invisible fluid to the sharp-eyed detectives and patrolmen. But as good as it is, under the present administration each

${ }^{1}$ Of the New York Police Department. 
meeting of the inspectors and the commissioner brings out the perfection of some detail, and a resultant steady improvement.

Notwithstanding the growing efficiency of this wonderful system of control, those wanted by the police not infrequently get away. Sometimes they slip through the first line of communications, to be picked up by the second. And again, they get by precinct lines, ferry and railroad terminals, only to be caught in the outlying suburban zones by police officers of another city or state.

Up to a short time ago, the system of communication consisted only of telephone lines from headquarters to precinct stations, and on to a limited number of posts in each precinct. These posts or "boxes," so called, were originally installed for the purpose of placing in the hands of the patrolman a direct wire to the lieutenant on his stationhouse desk. But when the patrolman had left his box, there was no way of calling him back until he returned to make his hourly report. The flash-light fills in this break in the connection. It is attached to the electric light posts on the street curb, and has five lenses. It may be seen in the day-time at a distance of 600 feet, and at night it is discernible nearly 2,000 feet. Attached to the same post is the iron "box" containing the telephone equipment. By turning a switch in the station-house, the lieutenant on the desk flashes the light on any post at intervals of four seconds. That light continues to flash until the officer wanted sees the call and goes to the telephone box and removes the receiver from the hook.

A citizen call-button is also attached to the "box," by means of which he may call an officer by merely pressing the button and lighting the lamp overhead, which throws a steady ray while the button is being pressed. Thus, by telephone and flash-light combined, all policemen on patrol are placed under the immediate supervision of the commanding officer at the station-house. He in turn is in direct communication with police headquarters and in case of an emergency the entire patrol force may be concentrated in a very short time.

The alarms at ferry houses, bridges and railroad terminals (flash-light and telephone) play a most important part in the interception of criminals, and the recovery of stolen property, particularly with the apprehension of automobile thieves and persons attempting to avoid arrest by trying to leave the jurisdiction of the city, is made possible although the fugitive may have a start of minutes and sometimes hours on his pursuers.

In the suburban sections of the city, such as the outlying districts of Queens, Brooklyn and Richmond, where the police stations are far apart, there has been established a system of police booths. In each booth, officers provided with a bicycle or motor cycle are stationed at all times. These booths have direct telephone connection with the station-house, also with the public exchange service. Booklets and 
maps are distributed to the residents giving the telephone number and location of booths, and other important information.

By these means, the large number of patrolmen otherwise required to cover that great amount of territory is eliminated, and the resident is provided with means of calling an officer, even more quickly than if a thousand patrolmen were walking posts. It takes but a minute to call the police booth, and only another two or three minutes for the patrolman to respond on his wheel, his place being immediately filled by another man from the precinct house who is sent out to relieve him.

Police Commissioner Arthur Woods is a firm believer in this auxiliary electric service, because it not only increases the physical efficiency of the department, but as such immediately becomes a powerful moral hazard to the crook who is about to commit a crime, and is therefore one of the very best preventive facilities that the Department possesses.

For many years, about twice the number of men on patrol during the day were assigned to patrol the city at night. The day force required is now fully as large as the night. But at the present time, however, few commanding officers will go back to the old idea of doubling the night patrol, and the utilization of electrical devices is, in a large measure, responsible for the change.

\title{
AN INDUSTRIAL TENDENCY WHICH PROVIDES THE OPPORTUNITY FOR THE CITY PLANNER
}

\author{
BY THOMAS ADAMS ${ }^{1}$ \\ Ottawa
}

$7 \mathrm{~N}$ "Satellite Cities" 2 we have an illuminating study of a modern tendency in industrial conditions in America-the tendency to remove industries from crowded centers to rural and semi-rural districts. It was precisely such a movement, among some of the great industrial concerns in England in the eighties, that formed one of the chief arguments that were used to secure the necessary public support to enable the first garden city to be established in that country. Fortunately for England two of the concerns which took part in this movement had at their heads men of great vision and statesmanlike qualities with the result that they took the opportunity which the transfer of their factories to spacious surroundings provided, to lay the foundations of two model industrial communities. The Bournville, of Messrs. Cadbury, and the Port Sunlight, of Messrs. Lever, both referred to in

1 Town Planning Expert, Canadian Commission of Conservation.

${ }^{2}$ Satellite Cities. By Graham Romeyn Taylor. New York: D. Appleton \& Company. National Municipal Lague Series. \$1.50. 